family allowances offer the best means of meeting unavoidable increases in living costs simultaneously for workers in all occupations with similar family needs, without stimulating a race between prices and wages.

Both Miss Rathbone's review and the broadsheet discuss systems and experience in other countries, and favour a national service, State-regulated and State-administered. Tabular statements included in Miss Rathbone's pamphlet show that the charge on the Exchequer ranges from $£ 118$ million for a Statepaid scheme, covering all children under fifteen years of age in Britain at $5 s$. per child, to $£ 6 \frac{1}{2}$ million for the State share of a contributory insurance scheme, covering only the population insured for unemployment at $3 s$., beginning with the second child. Miss Rathbone prefers a bold imaginative scheme, covering the entire child population at the rate of $5 \mathrm{~s}$. a child, on the grounds of justice, for eugenic reasons and because of the greater simplicity of administration. If this is considered too costly, a contributory insurance scheme is urged involving an Exchequer contribution of $£ 6 \frac{1}{2}-£ 32 \frac{1}{2}$ million. Whatever the scherne, payment of the allowance to the mother is strongly recommended, partly to diminish the attraction of the labour market to married women and partly to emphasize that the allowance is not part of the remuneration of labour, but a recognition of the child's value to the community.

\section{An International Air Force}

A PLAN for the organization of an International Air Force is outlined in the report of the Military Research Committee of the New Commonwealth Institute, which was printed just before the outbreak of the War but has only now been issued. The scope of the proposed Force is as a reinforcement of the self-defence of States, adequate to give each the sense of security from attack that its unaided strength, alliances, or guarantees of neutrality are unable to ensure. The scheme could only operate if a sufficient number of States consented to cooperate, and the report points out that absolute neutrality is inconsistent with co-operation against war by any plan. Associated States would make an annual contribution to a common pool, in equal proportion to their total resources or war budgets. The assistance afforded to each assured State would be the maximum possible and not determined by the amount of its contribution. After discussing the advantages and disadvantages of the alternative systems of a Force composed of national quotas and an independent organic Force recruited by voluntary enlistment, the report strongly recommends the latter. It is essential, that the Force should be as efficient, as homogeneous, and as certain to act when required as is humanly possible.

In regard to language, the Committee recommends the adoption of Spanish, and it is suggested that each contributing State should provide a base with extra-territorial status in its territory for the Force, this distribution of bases giving a wide area of protection, while the Force should have the maximum possible freedom of movement both in peace and in war. In regard to the supply of aircraft, the Committee contemplates drawing on the manufacturing resources of private firms in all States sufficiently prominent in aviation, and manufacture would be directed and supervised by a design department, a research department and an inspection department serving the Force. The contributing States would be represented on the Board of Control, although the Force would have complete internal autonomy and the power of executive initiative. In addition to an intelligence service, the High Command would be provided with simple standing orders to ensure rapid action after determination of the facts. The scheme is regarded as well within the ability of European and adjacent States to finance, organize, equip and recruit.

\section{Regional Organization and Local Government}

IN a paper entitled "Regional Organization during and after the War" read before the Royal Society of Arts on February 7, Brigadier Sir Edward Tandy described the regional organization developed for defence purposes and discussed its adjustment to meet peace-time requirements after the War. Reviewing our existing peace-time machinery for local government, which he urged must be accepted but reinforced by regional organization to meet emergencies like that of war, Sir Edward Tandy suggested that the easiest way to establish the regional organization required for peace would be to accept the system established for war and retain a suitable nucleus of staff at each regional headquarters. These headquarters would be available almost at once to form advisory committees to consider how new measures of reconstruction could be best applied to each region, or the best distribution within each region of any funds which might be allotted by the central Government for particular purposes. They could also assist as liaison officers in smoothing difficulties between the central Government and local government authorities and the like, and Sir Edward suggested that the commissioners should be designated Commissioners of Public Welfare, to indicate the wide general scope of their activities. Such regional organization could easily be discarded if it proved to be superfluous, but Sir Edward indicated the difficulties which are at present continually arising in the absence of a regional system for peacetime purposes.

\section{The Zoo during War-time}

THE report of the Zoological Society of London presented at the annual meeting on April 29 shows. that after the first great drop in public visitors last September to 11.3 per cent of the figures for the corresponding period of the previous year, there has been a healthy recovery. The Society is to continue its publications at about half the normal scale; 180 animals have been 'adopted' under the Society's war-time scheme to cover feeding costs and there have been developed photographic competitions to encourage amateur photography at the Zoo, and 